\title{
Occurrence of the Ascochyta blight pathogen, Ascochyta lentis, on lentil seed in Bolivia
}

\author{
W. J. Kaiser ${ }^{\mathrm{A}}$, G. M. Rivero ${ }^{\mathrm{B}}$, E. Valverde ${ }^{\mathrm{B}}$, L. Yerkes ${ }^{\mathrm{A}}$ and T. L. Peever ${ }^{\mathrm{C}} \mathrm{D}$ \\ A U.S. Peace Corps, Sucre, Bolivia. \\ ${ }^{B}$ Facultad de Agronomía, Universidad de San Francisco Xavier, Sucre 981, Bolivia. \\ ${ }^{C}$ Department of Plant Pathology, Washington State University, Pullman, WA 99164-6430, USA. \\ ${ }^{D}$ Corresponding author. Email: t.peever@wsu.edu
}

\begin{abstract}
Ascochyta lentis was isolated from necrotic lesions on lentil seed purchased in commercial markets throughout Bolivia in 2000. Incidence of seed infection ranged from $1 \%$ to $34 \%$ and the fungi isolated were able to reinfect lentil foliage in artificial inoculations. Disease spread from seed to seedling in the field was confirmed by planting infected seed in a field previously free of the disease and observing Ascochyta blight on the foliage. In addition, disease spread between plants initiated from infected seedlots to those initiated from clean seedlots and from infected plants back to seed was also detected. These observations indicate that A. lentis infection of lentil seed is common in Bolivia and may represent an important inoculum source for Ascochyta blight epidemics in commercial lentil plantings.
\end{abstract}

Lentil (Lens culinaris) is a minor crop that has been grown in Bolivia for several hundred years. Lentils are imported from several countries including Argentina, Canada, Chile and the United States, as local production does not meet consumer demand for quantity and quality. In a sample of lentil seeds purchased in the central market in Sucre, Bolivia in May 2000, some seeds were discolored with necrotic lesions. Isolations were made from the discolored seeds on potato dextrose agar and $2 \%$ water agar (WA). A pycnidial fungus was consistently isolated from the discoloured seeds, which was identified as Ascochyta lentis (teleomorph: Didymella lentis). Ascochyta blight of lentil in South America has previously been reported from Argentina and Chile (Bascur 1993). A larger sample of lentil seeds was obtained from markets in Aiquile, Cochabamba, Comarapa, La Paz, Monteagudo, Oruro, Padilla, Potosi, Santa Cruz, Sucre, Tarija and Tupiza. Vendors indicated that most seeds were imported from the four countries mentioned above. One hundred seeds from each market in each location were surface sterilised in $0.25 \% \mathrm{NaOCl}$ for $5 \mathrm{~min}$, plated on WA (20 seeds per $9 \mathrm{~cm}$ Petri dish), and incubated at room temperature. Ascochyta lentis was isolated from seeds of all samples, with seed infection rates varying from $1 \%$ to $34 \%$. Koch's postulates were fulfilled by inoculating foliage of 20-day-old seedlings of lentil cv. Pardina with spore suspensions $\left(1 \times 10^{6}\right.$ conidia $\left./ \mathrm{mL}\right)$ of three isolates of the pathogen from Potosi, Sucre and Tarija. Inoculated plants and controls (plants inoculated with sterile water only) were incubated in a moist chamber for 5 days at ambient temperatures and natural daylight. The fungus was reisolated from necrotic lesions on the leaflets, petioles and stems of all inoculated seedlings but not from control plants. The fungus was identified as $A$. lentis based on symptoms, cultural and morphological characteristics (Kaiser et al. 1994), and pathogenicity tests. To observe the spread and development of the disease under natural conditions, seeds of three lentil lines, two from Tarija (cv. unknown, incidence of seedborne A. lentis 23\% and 34\%, respectively) and one from the United States (cv. Pardina, incidence of seedborne A. lentis $0 \%$ ), were each planted in replicated trials at two sites near Sucre in late November 2000 where lentils had not been grown previously. Infection of the leaves was observed on all lines starting in mid-January 2001. Above average rainfall and cool temperatures during January to March favoured spread and development of the disease at both sites. The blight pathogen was disseminated $\sim 2 \mathrm{~m}$ from infected plants in the two Tarija plots to plants in the Pardina plots that were grown from pathogen-free seed. Rates of $A$. lentis seed infection of seeds harvested from the two sites ranged from $0 \%$ to $9 \%$. The teleomorph was not observed on naturally infected lentil debris. Ascochyta lentis is widely distributed in lentil seeds being sold in markets throughout Bolivia. This poses a threat to the country's lentil industry if $A$. lentis-infected seeds from local markets are planted by farmers, especially in years when environmental conditions favour the disease.

\section{References}

Bascur G (1993) 'La lenteja y el haba en America Latina: su importancia, factores limitantes e investigacion.' (ICARDA: Allepo, Syria)

Kaiser WJ, Hannan RM, Rogers JD (1994) Factors affecting growth and sporulation of Ascochyta fabae f.sp. lentis. Plant Disease 78, 374-379.

Manuscript received 29 March 2007, accepted 30 April 2007 